\title{
The 1972-1974 Eruption of Klyuchevskoy Volcano, Kamchatka
}

B.V. IVANOV

V.I. GORELCHIK

V.N. ANDREEV

A.M. MAKSIMOV

V.V. STEPANOV

A.M. CHIRKOV

\author{
Institute of Volcanology, FESC, USSR Academy of Sciences, Petropav- \\ lousk-Kamchatskii, 683006 USSR
}

\section{ABSTRACT}

A new Klyuchevskoy volcano eruptive cycle encompasses terminal (March 30, 1972 to August 23, 1974) and lateral (August 23, 1974 to December, 1974) eruption stages. The terminal eruption stage resulted in lava flows and parasitic cones that formed on the southwestern flank of the volcano.

Eruption products are moderately alkalic high-alumina olivine-bearing andesite-basalts. The terminal eruption stage was accompanied by volcanic earthquakes and volcanic tremor. The lateral eruption was accompanied by explosive earthquakes. Volcanic tremor was the most useful prognostic sign indicating the onset of the lateral eruption. Eruptive mechanisms are discussed.

\section{INTRODUCTION}

Since the end of the 1966 eruptive cycle, the Klyuchevskoy volcano has been in the state of slight fumarolic activity. From the early 1972 the activity of the terminal crater changed. The height of gas column increased up to $1000 \mathrm{~m}$ and more; and slight ash explosions began to occur within the crater. On the evening on March 30 a fiery glow appeared over the crater. Concurrently volcanic earthquakes with a focal depth of $0-15 \mathrm{~km}$ were recorded on the northeastern slope of Klyuchevskoy volcano. Furthermore, a continuous volcanic tremor, the amplitude of which increased continuously began to be recorded by all the seismic stations. The analysis of visual and seismic routine observations allowed us to consider March 1972 to be the beginning of a new eruptive cycle of Klyuchevskoy volcano.
The Terminal Eruption Stage had three consecutive phases. A phase of initial outbursts (from March 30, 1972 to April 6, 1974) showed a gradual increase of explosive activity (the height of explosions reached $1000 \mathrm{~m}$ ) first of Vulcano and next of Vulcano-Stromboli type. A phase of strong Vulcanian-Strombolian activity took place from April 6 to May 18, 1974. Phases of explosive activity were observed on April 6 to 13, 17 to 20 and on May 18 . During that time a scoria cone grew inside the crater quickly, and a small lava flow poured out. A phase of moderate steamgas activity took place from May 19 to August 23, 1974.

The Lateral Eruption Stage. Parasitic craters formed on the southwestern flank of the volcano in the region of "Svetly" glacier at an altitude from $3400 \mathrm{~m}$ (effusive-explosive center) to $3600 \mathrm{~m}$ (explosive crater). According to seismological data, the eruption commenced at $02 \mathrm{~h}$. $56 \mathrm{~min}$. GMT on August 23. The explosive crater had a shape of a funnel $60 \times 80 \mathrm{~m}$ in diameter, $10 \mathrm{~m}$ in depth and a small rim (1-2 m) around it. At the beginning of eruption the effusiveexplosive center involved several cones from 20 to $50 \mathrm{~m}$ in height. A blocky lava flow (Santorini type with scoria crust) poured out from a fissure near the foot of the lower cone. As a result of the lava flow-glacier interaction, a narrow glacial erosive canyon up to $\mathbf{4 0 ~} \mathrm{m}$ in depth formed. The lateral eruption stage consisted of three phases (Table 1): (I) strong initial eruption (August 23 to September 7); (II) moderate eruption (September 7 to 16); and (III) strong eruption (September 16 to 22) (Table 1). 
TABLE 1

\begin{tabular}{|c|c|c|c|c|c|c|c|}
\hline \multirow[t]{2}{*}{ Phesea } & \multicolumn{2}{|c|}{$\begin{array}{l}\text { Bxploaive } \\
\text { crater }\end{array}$} & \multicolumn{4}{|c|}{$\begin{array}{l}\text { Efruative-exploaive } \\
\text { center }\end{array}$} & \multirow[t]{2}{*}{ Dynanios of exaption } \\
\hline & $t_{1}$ & $\nabla_{1}$ & $t_{1}$ & $\nabla_{1}$ & $\nabla_{2}$ & $T$ & \\
\hline I & $20-30$ & $50-70$ & $20-30$ & $50-70$ & $0.5-0.6$ & $1000-1050$ & $\begin{array}{l}23.8-7.9 .1974 \text {. Intensive Vuloanian-Strombollan } \\
\text { activity, volcanic bombe are thrown out to a } \\
\text { helght of } 0.3 \mathrm{~km} \text {. Three sooris coner were formed } \\
\text { et an altitude of } 3400 \mathrm{~m} \text {. }\end{array}$ \\
\hline II & - & - & - & - & $0.1-0.2$ & $1000-1050$ & $\begin{array}{l}7.9-16.9 .1974 \text {. Slight oxplosive activity, calm } \\
\text { lava outpouring. }\end{array}$ \\
\hline $\operatorname{III}$ & $10-15$ & $70-80$ & $10-15$ & $60-70$ & $\mid \begin{array}{c}0.5-0.7 \\
\text { up to } \\
1.0\end{array}$ & $1000-1100$ & 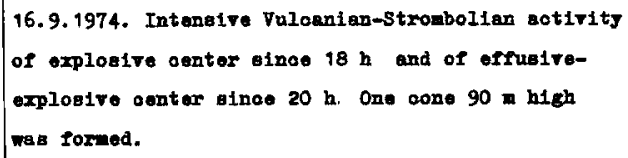 \\
\hline
\end{tabular}

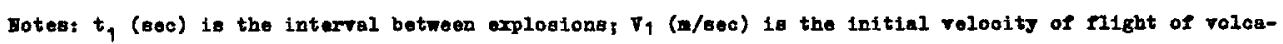

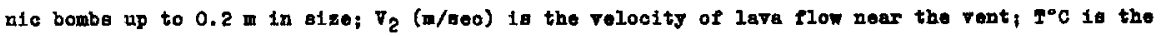
temperature of lave flow neer the rent determined with optiasl prrometer. The total volume of iseued lave 16 $0.02 \mathrm{ks}^{3}$. Disohargo of $\mathrm{B}_{2} \mathrm{O}$ during glacter melting $180.16 \mathrm{~m}^{3}$.

TABLE 2

\begin{tabular}{|c|c|c|c|c|c|c|c|c|c|c|}
\hline Oxiden & 1 & 2 & 3 & 4 & 5 & 6 & 7 & 8 & 9 & 10 \\
\hline $\mathrm{SiO}_{2}$ & 53.40 & 53.08 & 53.10 & 53.08 & 53.10 & 53.24 & 52.70 & 53.14 & 52.74 & 52.68 \\
\hline $\mathrm{THO}_{2}$ & 1.07 & 1.11 & 1.15 & 1.14 & 1.18 & 1.11 & 1.05 & 1.14 & 1.14 & 1.05 \\
\hline $\mathrm{Al}_{2} \mathrm{O}_{3}$ & 17.40 & 16.64 & 17.13 & 17.45 & 17.16 & 17.47 & 17.15 & 17.35 & 17.31 & 18.45 \\
\hline $\mathrm{P}_{2} \mathrm{O}_{3}$ & 3.58 & 4.06 & 4.53 & 3.21 & 3.05 & 3.92 & 4.83 & 3.85 & 3.28 & 3.28 \\
\hline$P \infty$ & 5.94 & 5.75 & 4.88 & 5.98 & 6.12 & 5.00 & 4.60 & 5.49 & 5.75 & 5.66 \\
\hline no & 0.15 & 0.17 & 0.17 & 0.16 & 0.16 & 0.16 & 0.16 & 0.16 & 0.16 & 0.13 \\
\hline $\mathbf{8} 80$ & 5.28 & 6.10 & 5.28 & 5.07 & 5.28 & 5.32 & 5.71 & 5.11 & 5.02 & 4.69 \\
\hline $\mathrm{CeO}$ & 8.02 & 8.54 & 0.87 & 9.00 & 9.20 & 8.94 & 9.14 & 8.94 & 9.14 & 9.39 \\
\hline $\mathrm{Ha}_{2} \mathrm{O}$ & 3.42 & 3.43 & 3.66 & 3.47 & 3.57 & 3.63 & 3.84 & 3.57 & 3.74 & 3.63 \\
\hline $\mathbf{z}_{2} \mathrm{O}$ & 1.13 & 1.16 & 1.25 & 1.16 & 9.16 & 1.20 & 0.94 & 1.22 & 1.16 & 1.09 \\
\hline$P_{2} O_{5}$ & 0.24 & 0.16 & 0.16 & 0.16 & 0,17 & 0.18 & 0.12 & 0.16 & 0.18 & 0.16 \\
\hline $\mathrm{B}_{2} \mathrm{O}^{+}$ & 0.54 & n.d. & n.d. & n.d. & n.d. & n.d. & n.d. & n.d. & n.d. & n. d. \\
\hline $\mathrm{H}_{2} \mathrm{O}^{-}$ & 0.36 & 0.36 & 0.36 & 0.34 & 0.34 & 0.34 & 0.32 & 0.36 & 0.32 & 0.26 \\
\hline Total & 100.53 & 100.72 & 100.54 & 100.22 & 100.49 & 100.59 & 100.56 & 100.49 & 99.94 & 100.47 \\
\hline
\end{tabular}

Iotes: 1-2 - aume1t orater ashog; 3 - axplonive oreter ashos; 4-5 - phase I lava; 6-9 - phase II lava, 10 - phase III Iara. Aneljaeg done at the Inotitute of Volosnology, FESC, USSR Aoad-ay of Sciences.

n.d. - not doteoted. 
TABLE 3.

\begin{tabular}{|c|c|c|c|c|c|c|c|c|c|c|}
\hline \multirow{2}{*}{$\begin{array}{l}\text { Emptive } \\
\text { phases }\end{array}$} & \multirow{2}{*}{$\begin{array}{l}\text { Volume } \\
\text { P1 }\end{array}$} & \multirow{2}{*}{ por } & \multirow{2}{*}{ cent } & \multicolumn{2}{|c|}{ phenocryste } & \multicolumn{4}{|c|}{ Phenocryat oomposition } & \multirow{2}{*}{$\begin{array}{l}\text { Quantitative Pl phenocryot ratios of the } \\
\text { ftrat and eocond generatione }\end{array}$} \\
\hline & & & & OPX & $\mathbf{m t}$ & P1 & 01 & CPx & OPX & \\
\hline I & 29.3 & 4.0 & 2.0 & - & 0.5 & An $70(60-75)$ & Po 7 & $\begin{array}{l}\log _{35} \\
\operatorname{ma}_{19}\end{array}$ & & 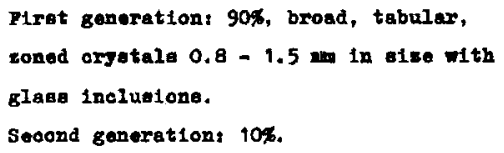 \\
\hline II & 28.2 & 7.0 & 1.0 & 0.5 & 2.0 & Ax 65(60-70) & $\mathrm{PO}_{78}$ & & $\mathrm{Pe}_{30}$ & 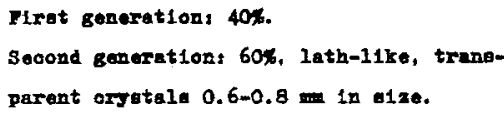 \\
\hline III & 28.0 & 4.0 & 1.0 & & 1.0 & An $70(65-75)$ & $\mathrm{No}_{7}$ & $\begin{array}{l}\operatorname{lo}_{45} \\
\operatorname{son}_{42} \\
P_{13}\end{array}$ & 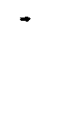 & $\begin{array}{l}\text { Hrat generation: 90\%. } \\
\text { Second genoretion: 10\%. }\end{array}$ \\
\hline
\end{tabular}

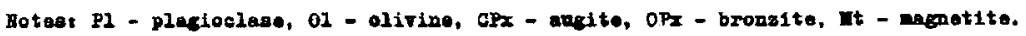

CHEMICAL, PETROLOGICAL AND GEOCHEMICAL CHARACTERISTICS OF ERUPTION PRODUCTS

The 1974 KJyuchevskoy eruption products are chemically and mineralogically high-alumina, olivine-bearing andesite-basalts containing moderate amounts of alkalis (Table 2). The mineralogical composition of erupted products is shown in Table 3 .

The composition of olivine from rocks of all 3 phases was determined using the microprobe "Cameca" (Table 4). A chrome-spinel grain was found in the center of the olivine grain (see Table 4). The composition of olivine: $\mathrm{SiO}_{2}-0.04$, $\mathrm{TiO}_{2}-1.03, \mathrm{Al}_{2} \mathrm{O}_{3}-8.95, \mathrm{Fe}_{2} \mathrm{O}_{3}-67.19$, $\mathrm{MnO}-0.29, \mathrm{Cr}_{2} \mathrm{O}_{3}-17.24, \mathrm{MgO}-6.74$, $\mathrm{K}_{2} \mathrm{O}-0.02$, total -101.50 . The chemical composition of pyroxene (eruption phase III) determined by microprobe: $\mathrm{SiO}_{2}$ 53.93, $\mathrm{TiO}_{2}-0.21, \mathrm{Al}_{2} \mathrm{O}_{3}-4.75, \mathrm{FeO}-$ 8.35, $\mathrm{MnO}-0.18, \mathrm{CaO}-19.78, \mathrm{MgO}-$ 14.14, $\mathrm{Na}_{2} \mathrm{O}-0.51$, total -101.85 .

The groundmass consists of microlites of plagioclase, olivine, pyroxene, magnetite and glass. A certain dependence has been established between the dynamics of eruption and a degree of groundmass crystallization. A decrease in size and amount of microlites was observed during eruption phases I and III.
TABLE 4.

\begin{tabular}{|c|c|c|c|c|c|c|}
\hline \multirow[t]{2}{*}{ Pasees } & \multirow[b]{2}{*}{$\mathrm{S}^{1 \mathrm{O}_{2}}$} & \multicolumn{4}{|c|}{ Oxtidos } & \multirow[b]{2}{*}{ Total } \\
\hline & & $P 00$ & mo & $\mathbf{1} 80$ & $\mathrm{CaO}$ & \\
\hline I & 40.94 & 19.72 & 0.28 & 42.71 & 0.13 & \{03.78 \\
\hline II & 39.85 & 19.99 & 0.29 & 40.65 & 0.14 & 100.93 \\
\hline III & 40.97 & 20.98 & 0.37 & 39.06 & 0.13 & 104.51 \\
\hline
\end{tabular}

\section{GEOCHEMICAL COMPOSITION OF ERUPTION PRODUCTS}

Table 5 shows the average abundance of minor and trace elements in eruption products and comparative data from similar rocks. There is little variation among minor and trace elements. However, attention may be paid to higher scatter in contents of trace elements in phase II and the lower one in phases I and III. In all probability, materials supplied to the surface during the periods of intensification of eruptive activity are compositionally more similar to pre-differentiates, i.e. they were not affected by the redistribution processes which occurred strongly during the calm eruption stage.

Minor and trace element abundances indicate that lavas tend to correspond to island arc tholeites. The ratio of $\mathrm{Cr} / \mathrm{Ni}$ and $\mathrm{Ni} / \mathrm{Co}$ shows evidence for the mantle origin of rocks. 
TABLE 5 - Average abundances of minor and trace elements in ppm.

\begin{tabular}{|c|c|c|c|c|c|c|c|c|c|c|c|c|c|c|c|c|}
\hline Book & $\begin{array}{l}\text { Frmber of } \\
\text { anslyeas }\end{array}$ & $T 1$ & $\nabla$ & $c r$ & 政 & Co & N1 & Son & mo & Pb & $\mathbf{x}$ & Na & $\mathbf{L 1}$ & Ro & $\mathrm{R} / \mathrm{Rb}$ & freferences \\
\hline \multicolumn{17}{|l|}{ Anhes: } \\
\hline Ternatnal etage & 4 & 8500 & 210 & 63 & 1400 & 22 & 527 & 7455 & 1,1 & 6.2 & & & & & & \\
\hline Lateral atage & 4 & 7000 & 190 & 55 & 1400 & 20 & 449 & 9271 & 1.9 & 6.9 & 8400 & 29200 & 12.6 & 13.2 & 644 & \\
\hline \multicolumn{17}{|l|}{ Andees to-beselto } \\
\hline Phase I & 8 & 6300 & 210 & 63 & 1000 & 18 & 408 & 8852 & 1.2 & 7.5 & 9000 & 27500 & 13.5 & 13.5 & 666 & \\
\hline Phase II & 33 & 5900 & 200 & 59 & 900 & 12 & 426 & 6965 & 1.2 & 6.9 & 9100 & 27600 & 12.7 & 94.1 & 674 & \\
\hline Phase III & 12 & 5800 & 210 & 45 & 900 & 20 & 387 & 7567 & 0.8 & 6.38 & 8200 & 24800 & 12.5 & 13.6 & 603 & \\
\hline $\begin{array}{l}\text { Internodiate ood- } \\
\text { anio tholelite }\end{array}$ & & 8100 & 292 & 297 & 11300 & 32 & $97-$ & -- & - & - & 1160 & 20000 & 6.0 & 1.1 & 1050 & 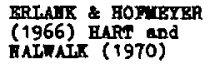 \\
\hline Ielond are theloifto & & 5600 & - & - & - & - & - & - & - & - & 3650 & - & - & 5.0 & 730 & JAKES * WHITE(1970) \\
\hline Continental tholeilte & & 6450 & 251 & 162 & - & 40 & $85-$ & -- & - & - & 7350 & - & - & 23.0 & 320 & 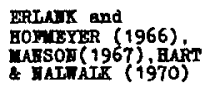 \\
\hline \multicolumn{17}{|l|}{$\begin{array}{l}\text { Aadesite-baealt of } \\
\text { recent klyuchorrakoy }\end{array}$} \\
\hline rolcano eruption & & - & 356 & 65. & & 41 & 551 & 118106 & 61.7 & 7.45 & 9700 & - & 15.0 & 16.0 & 600 & $\begin{array}{l}\text { IBONOTA \& EIRSA- } \\
\text { MOT }(1974)\end{array}$ \\
\hline
\end{tabular}

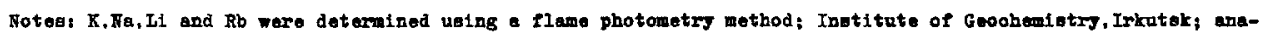
ljet G.I.SELIVANOVA. All other elementa were determined uging opeotral aneljaes acoording to a opacial

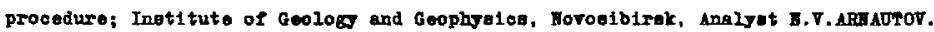

During the eruption the chemical composition of lavas varied slightly although an increase of $\mathrm{Al}_{2} \mathrm{O}_{3}$ and $\mathrm{CaO}$ and decrease of $\mathrm{SiO}_{2}$ in the course of eruption are the common feature of basaltoid melt differentiation under the lowpressure conditions. During the periods of strongest activity (phases I and III), lavas supplied to the surface correspond compositionally to deeper differentiates, i.e. materials that compositionally are more similar to parent magmas in comparison to lavas of the calm eruption stage. The distribution of minor and trace elements shows that the most variation in abundance is observed in lavas of the second calm eruptive phase. These peculiarities seem to be related to intensive «redistribution" of basaltic melt components in the near-surface environment (low-pressure differentiation of basaltoid magmas). The groundmass of andesite-basalts responds strongly to the character of eruptive actirity; a decrease of sizes and amount of microlites and ore minerals occurred during a period of intensification of volcanic activity. Petrochemical and geochemical characteristics of volcanics testify to their deep-seated (mantle) origin. This is also supported by the presence of chrome-spinel in the olivine grain in lavas of the first eruption stage. Judging from the chemical composition of the mineral and chrome abundance in lavas of eruption, spinel could not be generated under the low-pressure conditions, less than $3 \mathrm{~kb}$, from the melt containing 4$6 \times 10^{-3} \%$ chrome. It was generated during melting of rocks with higher chrome abundance under high-pressure and high-temperature conditions. According to data from DICKEY and YODER (1972), the higher $\mathrm{Cr} / \mathrm{Al}$ ratio in spinel is observed where the high-pressure and high-temperature spinels are generated.

\section{SEISMIC EVENTS}

From 1972 to 1974 three permanent and four temporary seismic stations were operating in the region of the Klyuchevskoy Volcano group. Errors in determining foci coordinates, surrounded by seismic stations, reached $\pm 2- \pm 3 \mathrm{~km}$ in depth and epicenter (GORELCHIK and STEPANOV, 1976). 
The type I volcanic earthquakes, according to Tokarev's classification (TOKAREV, 1966) were systematically recorded beneath the northeastern flank of Klyuchevskoy volcano. They appeared to be caused by magma migration within the edifice and deep-seated portions of the volcano. Before 1972 the prevailing focal depth of these earthquakes accounted for $0-10 \mathrm{~km}$, occasionally $15-20$ $\mathrm{km}$. In comparison to previous years, an obvious areal enlargement of the epicentral zone of the type I earthquakes was observed from the beginning of the new eruptive cycle.

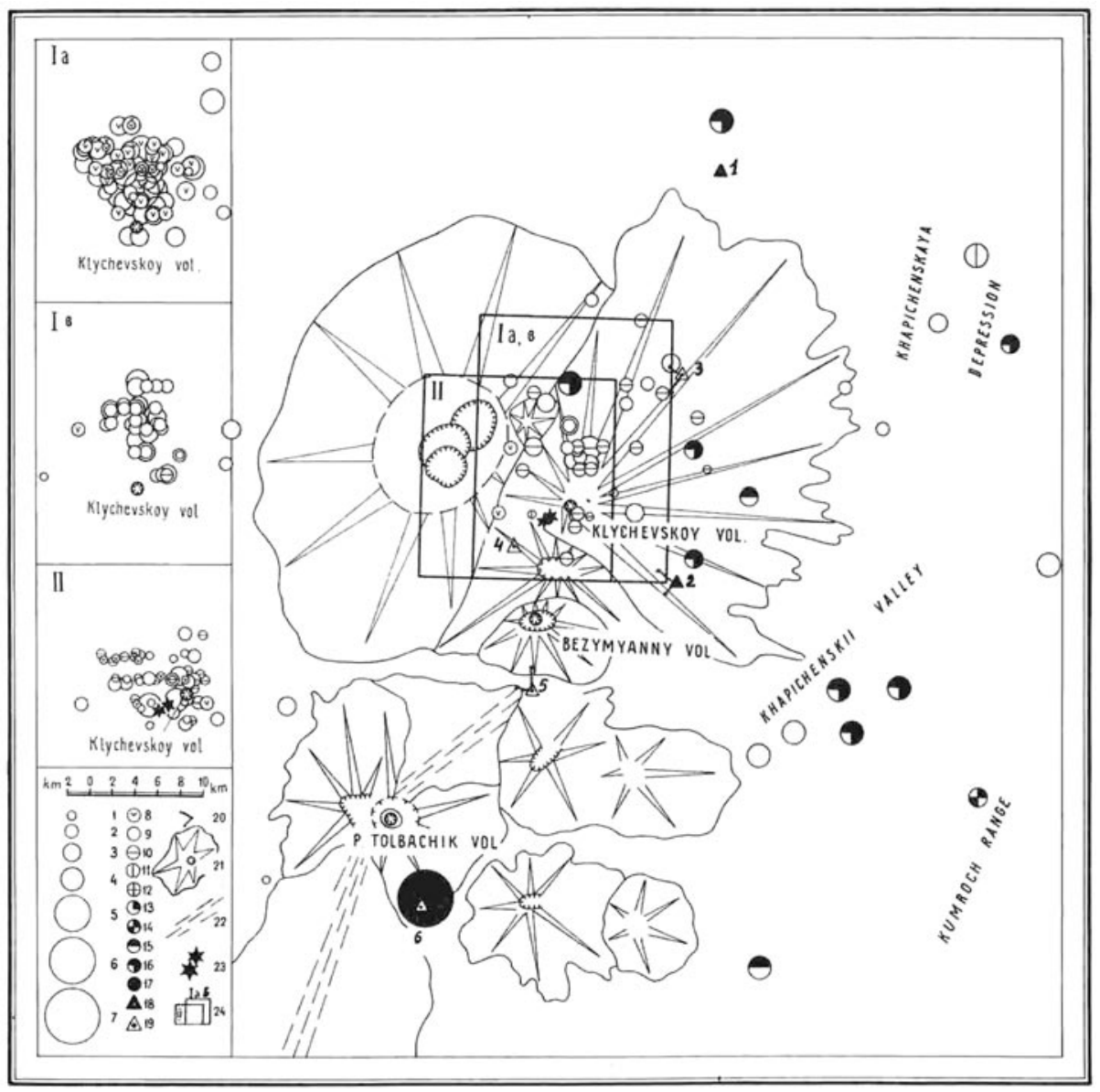

FIG. 1 - Map showing epicenters of earthquakes occurring in 1974 in the region of the Klyuchevskoy volcano group. 1 to 7 - energy classes of earthquakes $K=\lg E: 1-7,2-7,3-8,4-9,5-10,6$ $11,7-12 ; 8-17$ - depth of earthquake foci: 8 - above sea level, $9-0$ to $5 \mathrm{~km}, 10-6$ to $10 \mathrm{~km}, 11-11$ to 25 $\mathrm{km}, 12-26$ to $50 \mathrm{~km}, 13-51$ to $75 \mathrm{~km}, 14-76$ to $100 \mathrm{~km}, 15-101$ to $150 \mathrm{~km}, 16-151$ to $200 \mathrm{~km}, 17$ deeper than $200 \mathrm{~km} ; 18$ - permanent seismic stations, 19 - temporary seismic stations; 20 - profile stations; 21 - volcanic edifices; 22 - zone of basaltic flood volcanism; 23 - centers of the 1974 Klyuchevskoy lateral eruption; 24 - epicentral areas of earthquake swarms recorded from April 5 to 11, 1974 (I a), from April 16 to 23, 1974 (I b) and from August 14 to 20, 1974 (II). 


\section{Earthquake Swarms}

In addition to the type $I$ independent occasional volcanic earthquakes two earthquake swarms occurred in 1974 within the Klyuchevskoy edifice: the first in April, north of the crater, and the second in August, northwest, southwest and west of the crater. The second earthquake swarm preceded the lateral eruption (Fig. 1).

In the April swarm 333 earthquakes with $K_{\mathrm{S} 12}^{\mathrm{F} 68}\left({ }^{1}\right) \geqslant 7\left(K_{\mathrm{S}}^{\max }=10\right)$ and more than 800 earthquakes of smaller energy classes were recorded. In comparison to previous years, in April 1974 a seismically active area shifted closer to the Klyuchevskoy crater, to its northern flank. Two shock groups separated in time and different in earthquake type and prevailing focal depth can be recognized in the swarm. The first group (from April 1 to 5) consisted of the type II and III earthquakes with focal depths from $2 \mathrm{~km}$ below sea level to $3-4 \mathrm{~km}$ above sea level. The second group (from April 16 to 23) consisted of the type I earthquakes with focal depths of $0-5 \mathrm{~km}$ below sea level. From May to July 1974 the type I-III earthquakes were located as before around the Klyuchevskoy crater at depths 0-10 km and above sea level, shifting gradually to the southern flank.

A swarm of the type I-III earthquakes which preceded an outbreak of the Klyuchevskoy parasitic craters in August 1974 started its activity at depths of 5-10 km. It consisted of 33 earthquakes with $K_{8}>7$ and 95 earthquakes with $K_{8}<7$. The largest earthquakes $\left(K_{\mathrm{s}}=9\right)$ occurred at a depth of $0-5 \mathrm{~km}$ at the locality of the future eruptive centers. The epicentral zone of a swarm occurring in April was $100 \mathrm{~km}^{2}$ large, while the area of foci distribution in ground plan of earthquakes preceding the eruption was two times smaller. The focal depth seemed to decrease with time from $5-10 \mathrm{~km}$ below sea level to $2-3 \mathrm{~km}$ above sea level.

( ${ }^{1} K_{\mathrm{S1,2}}^{\mathrm{F} 68}$ is the energy class of earthquakes determined from $S$ waves using Fedotov's nomogram (FEDOTOV, 1972). $K_{\mathrm{Si}, 2}^{\mathrm{F} 68}=4.6+1.5$ $M$, where $M$ is the magnitude determined from the surface wave.

\section{THE TERMINAL ERUPTION STAGE}

The onset of terminal eruption coincided in time with an increase in the number and energy of the type I volcanic earthquakes beneath the northeastern flank of the volcano. In the course of terminal eruption and during the «preparation" for the lateral eruption, the area of intense cracking encompassed almost the whole portion of the edifice around the magma channel and crater (in ground plan) except for the locality of the future outbreak. Strong explosive activity of the summit crater occurred in April 1974 simultaneously with an intense swarm of volcanic earthquakes occurring on the northern and northeastern flanks of the volcano. However, the direct relationship between the swarm earthquakes and the state of the crater activity cannot be inferred.

There is a more distinct relationship between the state of the volcano and volcanic tremor whose energy increased by an order half a year before glow appeared in the crater. On the whole, from 1971 to July 1974 , i.e. by the onset of lateral eruption, the energy of volcanic tremor increased by four orders (Fig. 2). Two maxima associated with an intensification of the summit crater activity can be seen in the diagram $E_{\mathrm{tr}}(\mathrm{t})$. The first maximum $2.5 \times 10^{17} \mathrm{erg}$ for a 15-day interval or averaging $0.17 \times 10^{17} \mathrm{erg} /$ day was reached in May 1973. It occurred before an intensification of the summit crater activity which was noticed in September-October 1973 (explosions, ash emissions, glow) against the background of a fall of volcanic tremor energy. By the beginning of the ensuing intensification in the crater activity continuing from late February up to the end of May, 1974, the energy of volcanic tremor had reached on the average $0.3 \times 10^{17} \mathrm{erg} /$ day. During that period of time incandescent bombs thrown out from the crater could be seen for the first time in the eruptive cycle considered. By April 1974 (on April 9-12 the height and number of incandescent bombs were maximum) the energy of volcanic tremor exceeded two times the maximum value recorded in 1973 
$\left(0.45 \times 10^{17} \mathrm{erg} /\right.$ day $)$. It can be assumed that the average level of the volcanic tremor energy $\left(0.3 \times 10^{17} \mathrm{erg} /\right.$ day $)$ has been an "energy threshold" beyond which lava fountains appeared in the crater. From April 5 to 6 the energy of volcanic tremor diminished by two orders, then it increased gradually reaching $0.2 \times 10^{17} \mathrm{erg} /$ day and from April 17 to 20 when the second group of earthquakes appeared it decreased again abruptly. After April 21 volcanic tremor was recorded again and during May until June 20 the level of volcanic tremor remained almost the same, averaging 0.1 $0.2 \times 10^{17} \mathrm{erg} /$ day. From 1972 to June 1974 included, the mean amplitude of volcanic tremor varied from 0.1 to $1.2 \mu$. A period of oscillations accounted for $0.5-0.8 \mathrm{sec}$.

\section{LATERAL ERUPTION STAGE}

Changes occurred in the character of volcanic tremor after July suggesting the possibility of changes in the course of eruption. First, a period of oscillations became notably longer $(0.9-1.1 \mathrm{sec}$.) and, secondly, the polarization of seismic waves changed. By early August, the energy of volcanic tremor reached $0.2-0.3 \times 10^{17}$ erg/day. The mean amplitude of oscillations increased up to $2 \mu$.

The seismic "preparation" for the lateral eruption started on August 14 when the first swarm earthquakes appeared. It lasted approximately nine days until August 22 included. Volcanic tremor was absent at that time. The number of the swarm earthquakes with

FIG. 2 - Diagrams showing a 15-day change of seismic and volcanic activity according to data from seismic station 2 obtained during the period from 1972 to $1974 . E_{\text {tr }}$ is the energy of volcanic tremor in ergs; $N$ is the number of volcanic earthquakes occurring in the region of Klyuchevskoy volcano; $K^{\max }$ is the maximum energy class of earthquakes; $\mathrm{Nn}, \mathrm{Nc}, \mathrm{Nb}$ are the number of ash emissions, glow effects and explosions in the Klyuchevskoy crater, respectively for 15-day observations. 1 - the onset of terminal eruption; 2 - earthquake swarms, 3 lateral eruption.

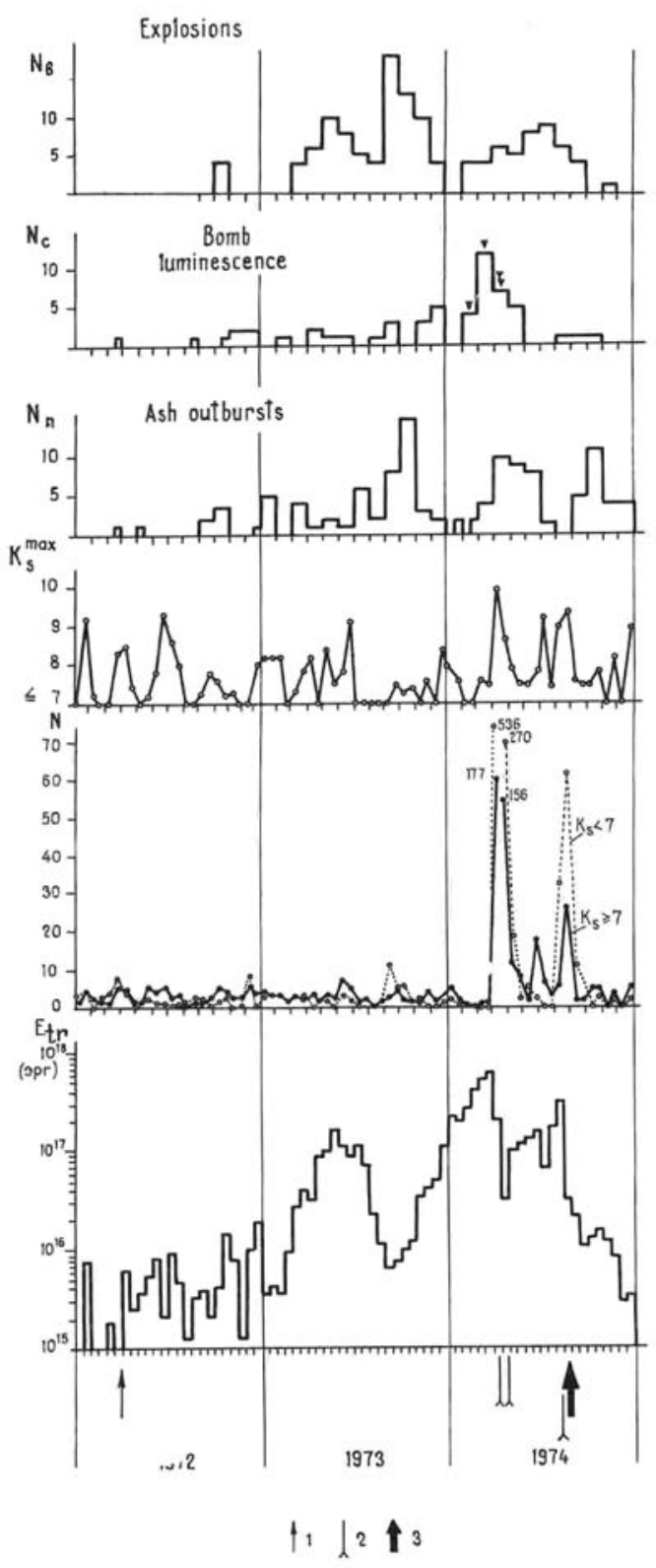


$K_{\mathrm{s}} \geq 7$ during the first five days has remained approximately the same, then it started to diminish abruptly. At the same time, the number of smaller earthquakes with $K_{\mathrm{g}}<7$ increased reaching a maximum value on August 22. By August 23 , the earthquake swarm had ceased and at $2 \mathrm{~h}$. $56 \mathrm{~min}$. GMT the first explosion earthquakes and volcanic tremor were recorded. The lateral eruption commenced.
Seismic activity before the 1974 eruption resembled a period of "preparation" for the lateral eruption of basaltic volcanoes. It differed from the April events, when, despite the higher energy and quantitative characteristics, the eruption did not take place. What are these differences? First, both the depth and direction of movements at depth were different. The depth of foci in the April swarm varied fro $5 \mathrm{~km}$ below sea level to $2-3 \mathrm{~km}$

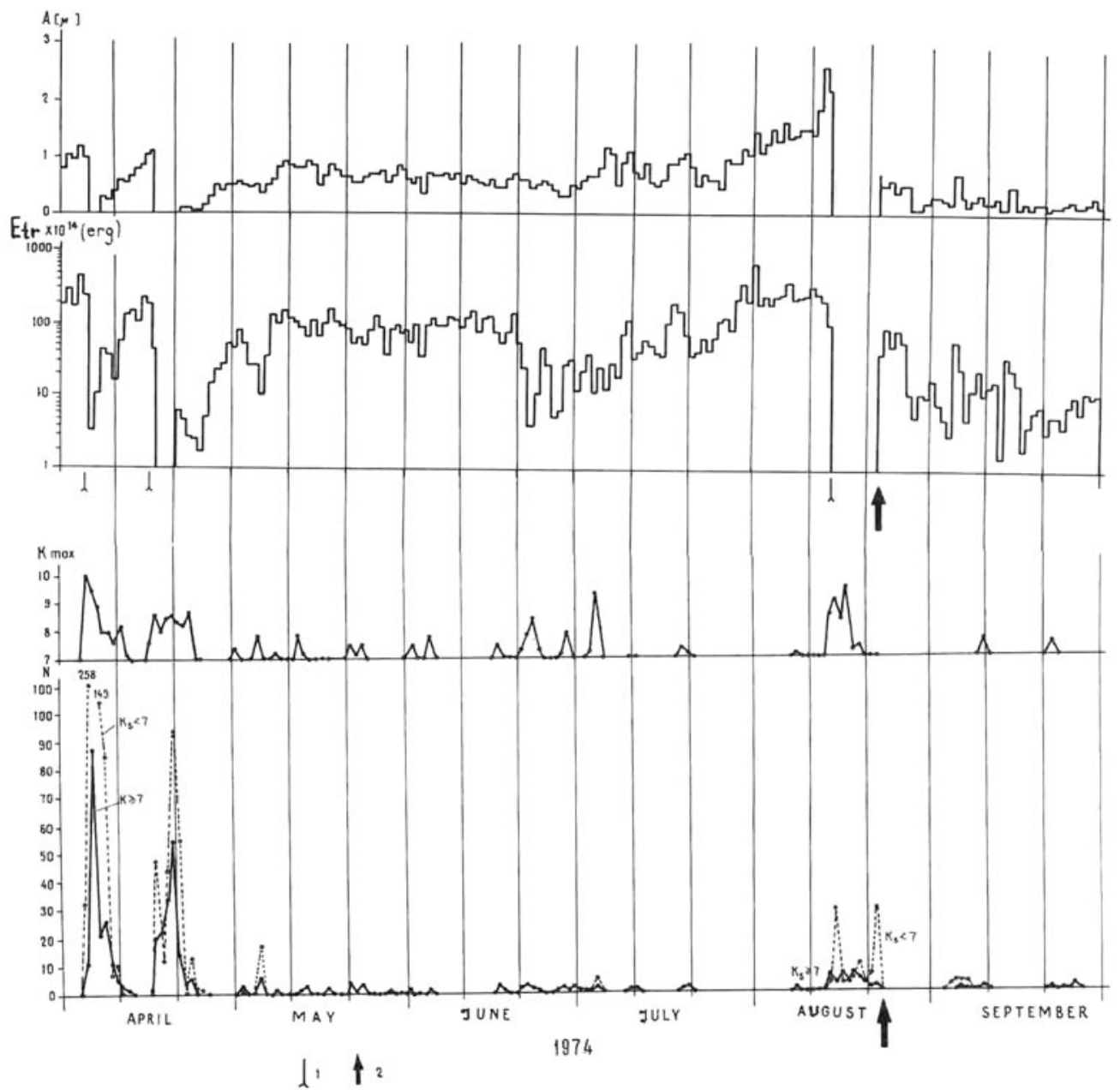

FIG. 3 - Diagrams showing daily changes in the number $(N)$ and maximum energy $\left(K_{\text {max }}\right)$ of volcanic earthquakes and of energy $\left(E_{\text {tr }}\right)$ and mean amplitude $(A)$ of volcanic tremor according to the 1974 data from seismic station 2. 1 - earthquake swarms, 2 - lateral eruption. 
above sea level. First, shallow ( -3 to 0 $\mathrm{km})$ and then deeper $(0$ to $5 \mathrm{~km}$ ) earthquakes predominated. Before the outbreak the first earthquakes of the August 14-23 swarm were recorded at a depth of about $10 \mathrm{~km}$, later on the number of earthquakes with a depth less than $5 \mathrm{~km}$ (shocks above sea level included), comparing to earthquakes with the focal depth of $5-10 \mathrm{~km}$, was continuously increasing until the eruption (Fig. 3). It is assumed from the seismic data that the magma was ascending to the eruption site from depths not less than $10 \mathrm{~km}$. Taking into account that the duration of the earthquake swarm was nine days, the velocity of magma ascent, $5 \mathrm{~m} / \mathrm{h}$, to the surface can be estimated to a first approximation. The second difference between the April and August earthquake swarms is the almost synchronous origin of earthquakes with $K_{\mathrm{s}} \geq 7$ and $K_{\mathrm{s}}<7$ in April and the reverse time dependence between the larger and smaller events observed before the eruption. The third difference is the absence of volcanic tremor during the swarm activity that is indicative of a period of "preparation" for the outbreak of parasitic craters.

After the onset of the lateral eruption, Klyuchevskoy volcano seismic activity was represented mainly by volcanic tremor and explosion earthquakes. The number of type I-III volcanic earthquakes occurring from September to December 1974 was small. Only some earthquakes were located in the region of outbreak at a depth of 10 to $3 \mathrm{~km}$. Most of earthquakes (one with $K=9$ ) were located beneath the southeastern and eastern flanks of the volcano. Volcanic tremor was the main "indicator" of the course of eruption. According to the change of energy and mean amplitude of volcanic tremor, lava started to flow probably at $20 \mathrm{~h}, \mathrm{GMT}$ on August 24 when the energy of volcanic tremor had fallen after its rise at the initial moment of eruption.

\section{MECHANISM OF LATERAL ERUPTION}

A mechanism of the lateral eruption was deduced from analyses of geological and geophysical data obtained from 1972 to 1974 .

During the period from March 30,1972 to April 6,1974 (phase of initial eruptions of the summit crater), the magma began to fill the upper portion of the conduit (the crater glow). The energy of volcanic tremor was slowly increasing, suggesting the possibility of magma movement within the conduit. Small groups of volcanic earthquakes, whose focal depth was less than $10 \mathrm{~km}$, occurred in the lowpressure zones beneath the northeastern flank of Klyuchevskoy volcano. They seemed to be a compensation to the "pushing" activity of moving magma and increasing inner pressure. It can be assumed that the magma filled deepseated portions of conduits whose vents were projected on these zones. In April and May 1974 (the second phase of the terminal eruption), the magma in the main volcanic channel reached the crater surface (fountaining and lava outpouring). However, the paroxysmal phase of eruption did not take place, probably due to lack of energy. Cracking of rocks in the volcanic edifice and magma intrusion along fissures at the depth of more than $0-2 \mathrm{~km}$ below sea level was caused by hydrostatic forces (an earthquake swarm of April 5-11). An earthquake swarm occurring on April 16 to 22 showed that cracking of rocks constituting the edifice of the volcano continued at depth, shifting to the main volcanic channel. As the magma migrated into the side parts of the edifice, its level in the main channel decreased again and glow above the crater ceased. In May and June (phase of moderate steamgas crater activity) during a period of relative seismic calm (earthquake swarms did not occur and the mean level of volcanic tremor was stable) the magma did not migrate. As a result, the so-called "magma cementation" occurred in the northern and northeastern parts of the edifice, consolidating essentially a weak zone. Judging from the energy of volcanic tremor which increased at that time, the magma started to move slowly to the surface in the main channel in July. Beginning from August 14, the magma was moving with a velocity of $5 \mathrm{~m} / \mathrm{h}$ along 
a system of fissures and channels branching from the main channel at a depth of about $5-10 \mathrm{~km}$. On August 23 the magma emitted onto the surface (the beginning of the lateral stage) in a weak portion of the edifice at an altitude of $3600 \mathrm{~m}$ above sea level in the southwestern part of the cone.

\section{REFERENCES}

DiCKeY, J.S., Jr. and Yoder, H.S., Jr., 1972, Partitioning Aluminum between Clinopyroxene and Spinel. Carnegie Inst. Annu. Rept. Dir. Geophys. Lab., 1971-72, Washington, D.C., p. 384-392.

ERI.ANK, A.J. and HoFmeYeR, P.K., 1966, $K / R b$ and $K / C$ s Ratios on Karroo Dolerites from South Africa. J. Geophys., 71-22, p. 54395446.

FEDOTOV, S.A., 1972, The Energy Classifica. tion of the Kurile-Kamchatka Earthquakes and the Problem of Magnitudes. Moscow, Nauka, 116 pp. (in Russian).

GORELCHIK, V.I. and STEPANOV, V.V., 1976, Seismicity in the Region of the Northern Volcanic Group of Kamchatha in 1971-1972.
In: Deep Structure, Seismicity and Some Peculiarities of Recent Activity of the Klyucheuskoy Volcano Group. Nauka, Vladivostok, p. 108-118 (in Russian).

HALBERG, J.A. and WILLIAMS, D., 1972, Archean Mafic Ultramafic Rocks Eastern Goldfields Region Australia. Earth and Planet. Sci. Letters, 15, p. 191-220.

HART, S.R. and NalWALK, A.J., 1970, K, Rb, Cs and $\mathrm{Sr}$ Relationship in Submarine Basalts from the Puerto Rico Trench. Geochim. Cosmochim. Acta, 34-2, p. 145-156.

JAKES, P. and WHITE, A.J.R., 1970, $K / R b$ Ratios of Rocks from Island Arcs. Geochim. Cosmochim. Acta, 34-8, p. 849-856.

LEONOVA, L.L., and KIRSANOV, I.T., 1974, Geochemistry of Basalts from Klyuchevshoy Volcano (Kamchatka). Geochimiya, 6, p. 875-883 (in Russian).

Manson, V., 1967, Geochemistry of Basaltic Rocks: Major Elements. In: Basalts. Interscience, New York, 1, p. 215-269.

TokareV, P.I., 1966, Eruptions and Seismic Regime of the Volcanoes of the Klyucheuskoy Group. Moscow, Nauka, 118 pp. (in Russian).

Ms. received Aug. 1978; sent to review Nov. 1978. Revised ms. received and accepted July, 1980 